\title{
Social Behaviour as a Basis for the Design and Development of Green Infrastructure
}

\author{
Barbara Goličnik Marušić
}

\begin{abstract}
Barbara Goličnik Marušić, Urban Planning Institute of the Republic of Slovenia, Slovenia (barbara.golicikmarusic@uirs.si)
\end{abstract}

\begin{abstract}
This paper addresses urban open spaces, their uses and users. It is concerned with spatial relationships between usage and the physical structure of open spaces in city centres, and addresses the social dimension of green infrastructures in cities and towns. On the basis of behaviour mapping, it reveals dynamic patterns of place occupancies as informative knowledge for responsive and inclusive design. The paper discusses the uses mapped in parks in two European cities (Ljubljana, Slovenia; Edinburgh, UK) under repeated observation on different days, at different times and under different weather conditions. It shows that occupancy patterns have some spatial logic and that in development, planning and design it is essential to pay more attention to the spatiality of uses, compatibility of uses in places, and comprehensive usage-spatial relationships to produce well used and people-friendly places. The paper is concerned with the practical aspects of the conduciveness of places to use and public responsiveness, and examines how different kinds of spatial structure facilitate use by different publics in different ways; and the extent to which such knowledge and awareness can inform design and decision-making.
\end{abstract}

Keywords: behaviour mapping, usage-spatial relationship, urban ladscape, public space, health

\section{Introduction}

In the nineteenth century, urban planning was recognised as an important tool to enhance social well-being and public health. Green infrastructure planning and the provision of green space in densely populated cities, in particular, exemplifies the present relevance of such planning approaches (e.g. in the United States with Olmsted's proposals such as central park in New York or park system of Boston). Although the modernist movement called for a usercentred approach and the provision of good living conditions for citizens (e.g. Le Corbusier, 1951; Le Corbusier, 1971), the focus of social well-being and public health policy in the twentieth century on city planning and design waned. Over the past few decades, awareness of the need to promote a healthy urban society has increased, and the role urban planning can play in improving the impact of urbanisation on public health has grown, especially in providing outdoor spaces and promoting physical activity. It is therefore important to understand cities as social processes and to inform planning and design by the user dimension without neglecting other factors (e.g., demographic, cultural, economic, structural, ecological and climatic) that influence and shape cities and their development.

This paper addresses the issues of green infrastructure planning and design, exploring social behaviour by means of behaviour mapping, a method for obtaining empirical knowledge for planning, design, and decision-making. It sees mapping and map-making in relation to the physical aspects of places and imaging, two subjects with which planners and designers are usually quite familiar. The paper posits that a body of such knowledge can effectively help designers and decision-makers in designing, evaluating, developing, and redeveloping places. The particular contribution of this paper is to stress the social dimensions of places:

- giving designers confidence that their proposed layouts will meet needs in practice and be used as predicted; 
- helping planning and decision-making authorities to discover restorative environments through the public's attachment to open spaces and their recreational habits, and to interpret their healthier lifestyles;

- helping planning and decision-making authorities to recognise the range of peoples' needs, habits and expectations in open spaces through information on user and age groups and the gender-referenced characteristics of place users.

\section{Background}

Ward Thompson (2013: 79) notes that the recent revival in policy interest in environmental design and its potential contribution to health has been partly due to the current health crises in the Western world, not least the rising levels of obesity, type 2 diabetes, cardio-vascular disease, cancer, and mental illness, and their consequences for the cost of healthcare. According to Ward Thompson (2013: 80), environments that support healthy behaviours and responses may have more permanent and population-wide effects than other forms of public health interventions targeted at individuals. The literature shows that contemporary health researchers examining physical activity (e.g. Hardman and Stensel, 2003; Sallis et al., 2008; Sugiyama et al., 2008; Sallis et al., 2012) have used so-called socioecological models in which the built environment plays an important role in facilitating or inhibiting participation in physical activity.

The theories behind contemporary research on activity behaviours and the planning and design of outdoor spaces are mostly grounded in environmental psychology, e.g., affordances (Gibson, 1979) and behaviour settings (Barker, 1976), but are gradually being adopted for the focussed purposes of planning or design. Heft (2010: 18) notes that: "affordances are perceptual properties of the environment that have functional significance for the individual." Ward Thompson (2013: 81), drawing parallels with research informing planning and design argues: "By emphasising the information available from the surrounding environment as key element of landscape users' perception and action, the concept of affordances is attractive to planners and designers because it opens up ways to consider how the physical environment might be managed or manipulated to support different human experience and activities." There is a considerable body of work addressing landscape perception in relation to preferences and aesthetics (e.g., Kaplan and Kaplan, 1989; Bourasa, 1991), providing a theoretical and inspiration basis for research on restorative landscapes and environments to support mental well-being, mostly linking natural environments, physical activity, and psychological restoration (e.g. Hartig et al., 2003; Hartig, 2007).

Behaviour setting is defined as the relationship between the social and environmental characteristics of places and refers to a standing pattern of behaviour tied to a particular place and time (Baker, 1976). In practice, this means that certain types of place, including sociocultural contexts, are expected or predicted to elicit certain types of behaviour. Behaviour maps, records of behaviour patterns in places and a tool for analysing and evaluating usagespatial relationships (Goličnik, 2005; Goličnik Marušić and Marušić, 2012), are strongly linked to behaviour settings: in a very literal sense behavioural mapping provides the footprint of a behaviour setting. For example, repeated behaviour patterns of skateboarders in central public squares constitute a platform at least $3 \mathrm{~m}$ wide, attached to a step at least $15 \mathrm{~m}$ in length, to allow the skateboarders' minimum preparation journey for a jump and slide over such a step (Goličnik Marušić, 2011), while such behaviour would not be found in sizable platforms with no attached steps or steps significantly shorter than $15 \mathrm{~m}$. Behaviour settings offer a useful unit for analysing how aspects of environmental design relate to people's activities in places, and behaviour mapping is hence a tool for visualising and monitoring usage-spatial relations, and can accordingly guide socially sustainable design. 
The outdoor environment, particularly public open spaces such as parks and green spaces, is one of the milieus that can offer opportunities for a variety of physical activity behaviours. This paper focusses on relationships between physical activities and environmental settings to appraise opportunities for physical activity and provide some evidence about the (active) lifestyles of urban inhabitants. The paper takes the view that it is possible to create attractive parks and other outdoor spaces that encourage and facilitate physically active behaviours; not only walking (which in recent decades has been promoted and studied) with a favourable impact on public health) but above all long-stay activities in places such as ball and frisbee games, or skateboarding - typical urban activities for the young. For this reason, there is a particular interest in how the design of everyday environments can support and encourage physical activity.

Koohsari et al. (2015) find that research on relations between public open spaces and physical activity is increasing, but point to the conceptual and methodological gaps that still limit such research. GPS devices, pedometers or accelerometers are often used to collect data on physical activities in defined places (e.g. Coombes et al., 2013; Dunton et al., 2014; Evenson et al., 2013). Such studies are usually limited to one type of activity and peoples' participation is conscious. The literature also focuses on particular groups such as children, using similar approaches and the above mentioned tools (Quigg et al., 2010). Studies concentrate mainly on health issues; what contribution planning can make to improving public health with regard to spatial dimensions and measures to be taken are given only vague consideration. Similarly, Goličnik (2005) recognises the applicability gap between social science research and place design, pointing out the importance of empirical knowledge about usage-spatial relationships to be gained by observation and behaviour mapping and emphasising the role of GIS-supported techniques of spatial annotation and visualisation.

Hence, it is crucial for planning and design practice to take the conduciveness of places to physical activities into account, to gain a better understanding of how the attributes of green spaces relate to physical activity and how different user groups engage with spaces. Research methods that ensure unobtrusive observation and produce up-to-date information about given situations and for simulation purposes are essential, especially to capture the spontaneity of activities in places and examine the range of people using a place. This paper accordingly focusses on the temporal and spatial characteristics of dynamic patterns in public spaces; their dimensions, intensity and frequency, and on the necessary buffers between activities and between activities and spatial structures. This increases the range of active behaviour studies addressing the impact of urban planning and design on health, taking a step towards userinformed guidance for planners and designers.

\section{Methodology}

Behaviour mapping data on selected open spaces in central Ljubljana were collected on several occasions in May 2003 through systematic, comprehensive observation. The sample included eight public open spaces: Tivoli Park, Zvezda Park, Argentinski Park, Trg republike, Plečnikov trg, Dvorni trg, Mestni trg and Prešernov trg. May was chosen because the weather was likely to be warm and outdoor activity pleasant. Observation was timed to capture likely patterns of use at different times of the day and on different days of the week. There were four observation periods: $10 \mathrm{am}-12$ noon; $12-2 \mathrm{pm} ; 2-4 \mathrm{pm}$ and $4-7 \mathrm{pm}$. The observation protocol involved a systematic walk through each place, visiting all sub-areas and taking a 10minute visual scan of each sub area. All users observed during the scan were recorded as point data on detailed maps of the sites $(1: 1000$ scale) using symbols corresponding to the activities observed. They were accompanied by additional data, such as duration of an activity (e.g., less than 1 minute, $1-2$ minutes, $2-5$ minutes, longer than 5 minutes) and estimated age class for each person (e.g. up to 5, $6-12,13-19,20-34,35-50,51-65$, and over 
65). At the same time, the areas occupied by certain activities were documented on a map. The weather conditions - temperature, wind, dryness, and sunshine - for each observation period were also recorded. Altogether 106 observations were made in Ljubljana. The author has several sets of observation data for the Ljubljana parks discussed in this paper (e.g. Goličnik et al., 2007; Goličnik Marušić, 2009) showing that behaviour patterns noted in the original research (Goličnik, 2005) still apply despite some renovation works.

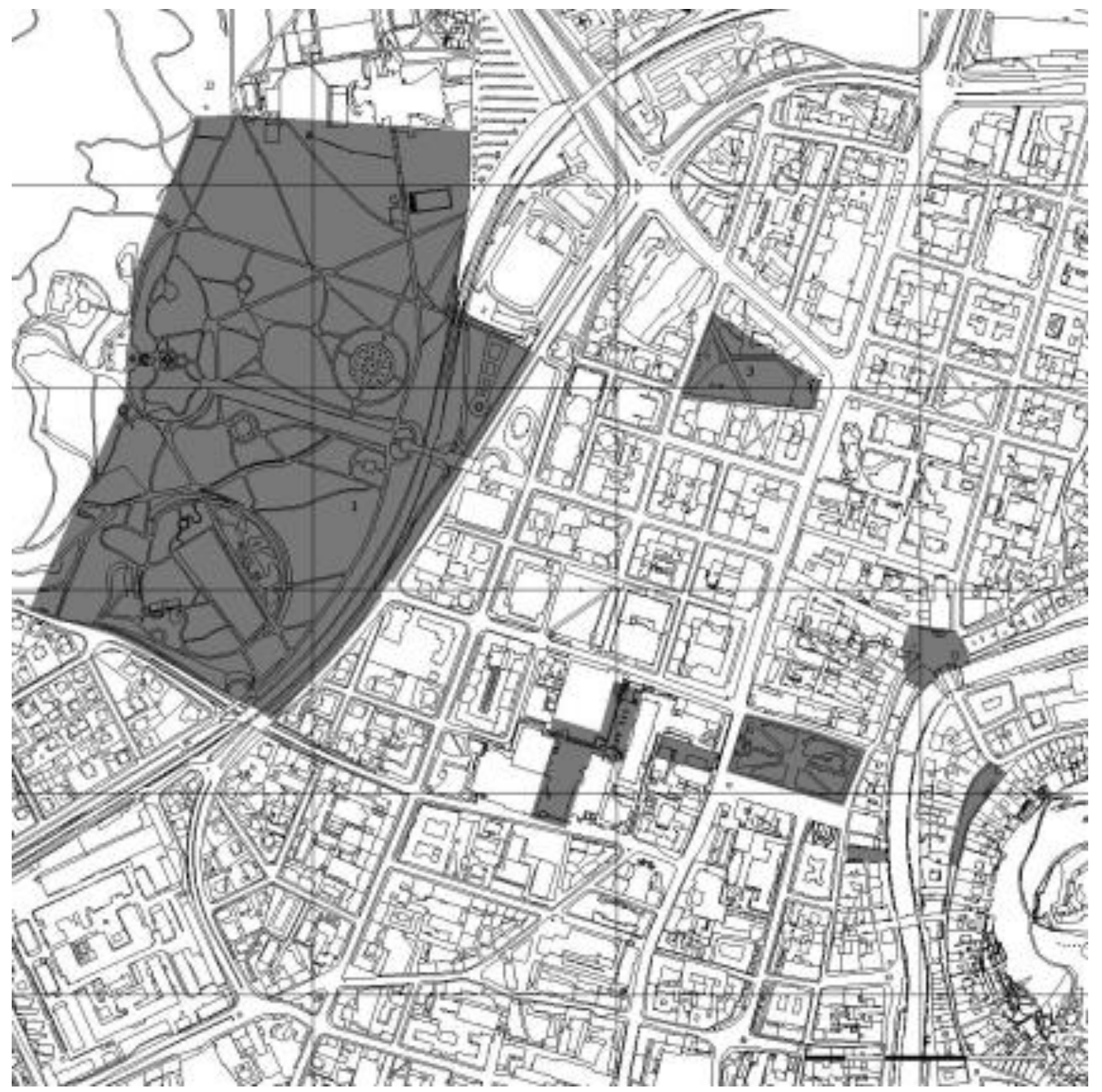

Figure 1: Selected sites included in the original research with special annotation to cases examined in this paper: 1. Tivoli park, 2. Zvezda park, 3. Argentinski park (source: Goličnik, 2006).

This research (Goličnik, 2005) focussed on the use of less clearly defined spatial settings and how spontaneous and informal uses in central parks and squares co-habit and co-shape places. Although behaviour mapping requires a clear observation protocol prepared in advance, it must remain open-ended to enable the most interesting, most important, or richest data on the territory to be collected. Some early observations already showed differences between places in the intensity and frequency of use, as well as the variety of users. In the defined time frame for observation, places with a greater variety and intensity of uses were 
therefore observed more often, whereas those with lower social dynamics - used mostly for usual activities such as walking, cycling, and waiting/standing - were given less frequent attention. The observation time-table was also adapted to allow for extremely bad weather conditions or the occasional cultural or sport public event which suspended the daily routine in the place. The data collected is reliable, as observations were repeated on different days, at different times of day, and under different weather conditions.

The final database was organised in a GIS supported environment (ESRI, ArcView 3.3), where datasets on a daily basis for each place provide behaviour maps consisting of layers of information including the type and duration of an activity, and the age group and gender of the persons engaged in an activity. This permitted postulation about passive or active engagement in places and about people's recreational habits and lifestyles.

\section{The Case Study: Central Parks in Ljubljana}

Although both squares and parks are public open spaces and as such constituents of green infrastructure, their role and meaning in the public lives of citizens differ. Parks are usually described as places for rest, relaxation, and active recreation. They are usually bigger and predominately green. In comparison to squares they are settings with less explicit limits, and usually serve a greater variety of uses. The spatial determination and articulation of park settings are often less defined on a small scale than squares, but are often defined on a larger scale in terms of surface, size, shape, and physical as well as programme articulation. In this context, a physical articulation refers to level changes in and between main surfaces (lawns) and the quality of outer and inner boundaries, for example, a solid boundary such as the edge of a parks' woodland, a transparent boundary such as a tree line, and an indication of horizontal divisions such as paths or dikes. The inner partition of park surfaces thus defined is usually marked by different elements such as single trees or groups of trees, and on a smaller scale, also by water motifs, walls and benches, for example, which address the programme articulation of a park, too.

For the purpose of this paper, parks in central Ljubljana were selected from the sample for the entire research to discuss social behavioural values in the design and development of green infrastructures in cities or towns. All the parks included were green spaces with no large built structures and with a similar maintenance policy. This chapter outlines the historical facts and spatial context of the parks; their usage-spatial characteristics are discussed under 'Results.'

\section{Large Central Park: Tivoli}

Tivoli is the largest public park in central Ljubljana; its physical appearance is the product of centuries. The last crucial changes reflected in current uses date from the 1960s, when railway and road construction significantly changed the eastern side and reduced both physical and visual links with the city centre. The last visible changes date from the 1990s, when a new children playground was introduced in the southernmost part of the park and the adjoining pond and greenhouse area was renovated. As far as the spatial context and social programme of Tivoli are concerned, the vicinity is characertised by residential areas, including student accommodation, galleries, museums, outdoor cafés and a children's playground in an adjoining area. The park's location and the spatial features of its context are marked by a railway corridor and the slopes of a hill, with inner articulations and slight slopes in some parts. Although Tivoli, as a park, is part of a larger recreational area attached to a natural urban forest, and is equipped with some sport facilities at the northern end for in- and outdoor activities, a distinctive area of green open space forms a recognisable spatial entity, and this has been included in the study as a park. It covers about $230000 \mathrm{~m}^{2}$. Besides 
recreation, the sense of place of the park is as a space for rest and relaxation, equipped with traditional park amenities such as benches and fountains.

\section{A Square-like City Centre Park: Zvezda}

Zvezda Park is a green part of the square Kongresni trg, initially laid out for the 1821 meeting of the Holy Alliance in Ljubljana. It is the oldest public park in the city. The boundaries of the square are defined by a compact built frame of buildings from various historical periods of mixed uses. The green part is spatially articulated by a star shaped system of crossing paths. The park contains some symbolic-historical features and other landmarks such as a fountain. Over the past decade, Kongresni trg has undergone various changes. First, the traffic regime has been altered. A few years later the entire square was renovated, attaching the green part to the vast paved area (pedestrian zone) previously used for parking. The data used in this paper on the spatial usage of the green area is taken from Goličnik (2005). However, observations have been carried out subsequent to the changes in the area (Goličnik et al., 2007; other author's archives) that show that recent modifications have not significantly influenced the usual patterns of use and confirm that the data used are still relevant for our purposes.

\section{Neighbourhood Park: Argentinski Park}

Argentinski Park is a small neighbourhood park in the city centre. Besides residential land use in the vicinity, there is a primary school and a kindergarten, various services, cultural institutions, and administrative and government offices. The park includes a children playground, which is not fenced off and is openly accessible. There is a restaurant at the far eastern end and a small café at the edge of the park, too. There are two significant residential areas adjacent to the park: the larger of the two, characterised by the Dukič apartment blocks at the southern edge of the park dating from the interwar period, and a smaller apartment block built as a local urban regeneration project at the northern end of the park, with the ground floor facing the park accommodating design shops. There is a large vacant site across the local one-way street defining the western edge of the park, which according to planning documents is earmarked for a national cultural centre. However, political and investment issues have halted development.

\section{Results}

The parks under study differ in size, character and historical-symbolic value; however, they are green patches of the city used by its inhabitants, and from a structural, ecological and social perspective are valuable elements of the green infrastructure of Ljubljana. This paper focusses on the social dimensions of green infrastructure; our concern is therefore people's engagement with places and the behaviour patterns of place occupancies. Tivoli, the largest city park, is in constant and diverse use, mostly passive activities such as sitting on the grass or benches; and transitory activities such as walking and jogging. Long-stay activities such as ball games were not observed often. Characteristic of the daily routine in Zvezda Park are transitory activities such as walking and cycling, as well as roller-skating (after the re-design of the pathing a few years ago which replaced the hard surface by sandy cover, the pattern of roller-skating changed; skaters have since moved more frequently to the now traffic-free paved surfaces adjoining the green patch) and as a place for meeting, mostly standing, but also seated on benches and the grass. Use in Argentinski Park is considerably less intensive than in Tivoli or Zvezda; however the types and nature of activities are similar to those observed in Tivoli. 
Table 1: Number of users engaged in an activity and frequency of appearance of activities (very often $\mathrm{VO}$, often $\mathrm{O}$, rarely $\mathrm{R}$, very rarely $\mathrm{VR}$ ) in observed parks in the entire observation period.

\begin{tabular}{|c|c|c|c|}
\hline & $\begin{array}{l}\text { Tivoli } \\
(\mathbf{N}, \%, \quad \text { fr. })\end{array}$ & $\begin{array}{l}\text { Zvezda } \\
(\mathrm{N}, \quad \%, \quad \text { fr. })\end{array}$ & $\begin{array}{l}\text { Arg. Park } \\
(\mathrm{N}, \% \text {, fr.) }\end{array}$ \\
\hline Walking & $885,25 \%, \mathrm{VO}$ & $1015,53 \%, \mathrm{VO}$ & $422,63 \%, \mathrm{VO}$ \\
\hline Sitting on a bench & $485,13 \%, \mathrm{VO}$ & $304,16 \%, \mathrm{VO}$ & $32,5 \%, \mathrm{VO}$ \\
\hline Sitting on the grass & $459,13 \%, \mathrm{VO}$ & $117,6 \%, \mathrm{VO}$ & $18,3 \%, \mathrm{VO}$ \\
\hline Cycling & $330,9 \%, \mathrm{VO}$ & $139,7 \%, \mathrm{VO}$ & $53,8 \%, \mathrm{VO}$ \\
\hline Pushing a pram & $122,3 \%, \mathrm{VO}$ & $24, \quad 1 \%$ & $18,3 \%$ \\
\hline Walking a dog & $138,4 \%, \mathrm{VO}$ & $5, \quad<1 \%, \quad \mathrm{R}$ & $14,2 \%, \mathrm{VO}$ \\
\hline Walking a child & $197,6 \%, \mathrm{VO}$ & $22, \quad 1 \%, \quad \mathrm{O}$ & $7, \quad 1 \%$ \\
\hline Lying down & $113,3 \%, \mathrm{VO}$ & $9, \quad<1 \%, \quad \mathrm{R}$ & / \\
\hline Standing & $78, \quad 2 \%, \mathrm{VO}$ & $194,10 \%, \mathrm{VO}$ & $7, \quad 1 \%$ \\
\hline Sitting around a table & $457,13 \%, \mathrm{O}$ & $75, \quad 4 \%$ & / \\
\hline Rollerskating & $131,4 \%, \quad \mathrm{O}$ & $20, \quad 1 \%$ & $5, \quad<1 \%, \quad \mathrm{R}$ \\
\hline Jogging & $66, \quad 2 \%, \quad \mathrm{O}$ & $<1 \%, \mathrm{VR}$ & / \\
\hline Playing & $1 \%, \quad \mathrm{O}$ & $<1 \%, \quad \mathrm{R}$ & $44,7 \%$ \\
\hline Lying down on a bench & $10,<1 \%, \mathrm{O}$ & l & / \\
\hline Sitting with a pram & $12,<1 \%, \mathrm{O}$ & l & $4,<1 \%$ \\
\hline Playing frisbee & $14,<1 \%, \quad \mathrm{R}$ & l & / \\
\hline Playing football & $25,<1 \%, \quad \mathrm{R}$ & l & $42,6 \%$ \\
\hline Climbing & $<1 \%, \quad \mathrm{R}$ & l & \\
\hline Playing with a ball & $<1 \%, \mathrm{VR}$ & l & $3,<1 \%, \mathrm{VR}$ \\
\hline Playing wolleyball & $<1 \%, \mathrm{VR}$ & / & / \\
\hline Propelling a scooter & $<1 \%, \mathrm{VR}$ & / & / \\
\hline BMX acrobatics & $<1 \%, \mathrm{VR}$ & l & / \\
\hline Skateboarding & $<1 \%, \mathrm{VR}$ & l & / \\
\hline Exercising & $<1 \%, \mathrm{VR}$ & l & / \\
\hline Fishing & $<1 \%, \mathrm{VR}$ & l & / \\
\hline Playing badminton & $<1 \%, \mathrm{VR}$ & / & / \\
\hline Using wheelchair & $<1 \%, \mathrm{VR}$ & l & / \\
\hline Sitting with a dog & $<1 \%, \mathrm{VR}$ & $<1 \%, \mathrm{VR}$ & / \\
\hline Walking a child and a pram & $<1 \%, \mathrm{VR}$ & l & $<1 \%, \mathrm{VR}$ \\
\hline Sitting on the tree & $<1 \%, \mathrm{VR}$ & l & l \\
\hline
\end{tabular}

\section{Tivoli}

The research underlying this paper focused on the potential of a variety of park settings to accommodate one or more uses; it therefore concentrated on spontaneous and informal activities rather than formal uses attached to particular settings purposely designed for them. For example, designed playgrounds and open air sport facilities were not included. Diversity in the activities recorded in Tivoli lies in rare, sporadic uses, rather than conventional, regular pursuits, such as walking or sitting. Less often recorded activities were for example frisbee and ball games, football, and tree climbing; only once or twice were activities such as bmxacrobatics, badminton, skateboarding, and exercising recorded. 


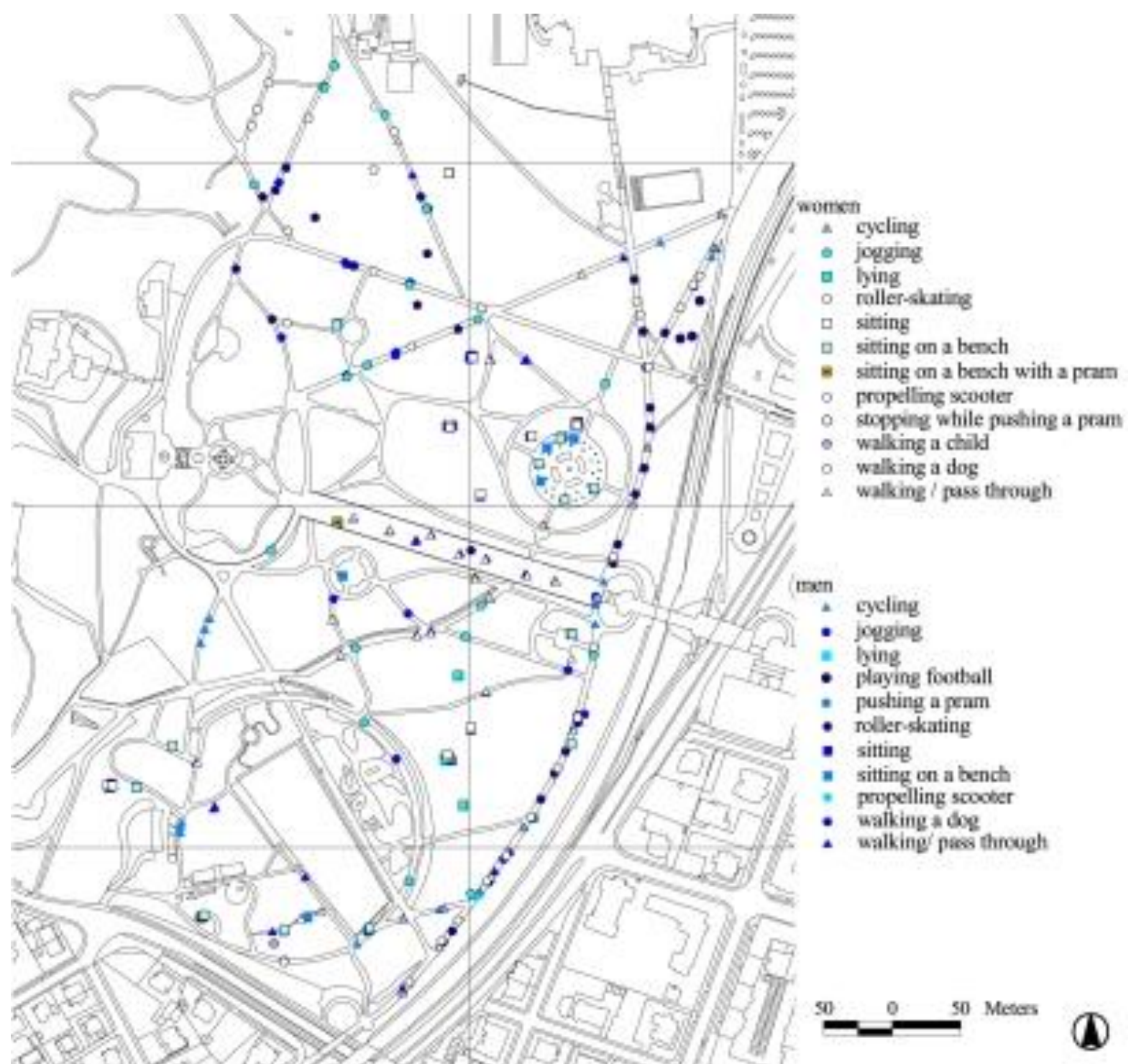

Figure 2: Typical daily pattern of usage in Tivoli, recorded in good weather conditions, late afternoon during the week (source: Goličnik, 2005).

Table 2: Intensity of often recorded activities in Tivoli over the entire observation period.

\begin{tabular}{lll}
\hline Activity & Max number & Frequency \\
\hline Walking & 95 & 21 of 21 \\
Sitting on a bench & 44 & 21 of 21 \\
Pushing a pram & 20 & 20 of 21 \\
Sitting & 59 & 18 of 21 \\
Cycling & 54 & 18 of 21 \\
Walking a dog & 23 & 18 of 21 \\
Walking a child & 68 & 17 of 21 \\
Lying & 15 & 17 of 21 \\
Standing & 23 & 17 of 21 \\
Sitting around a table & 54 & 15 of 21 \\
Rollerskating & 35 & 14 of 21 \\
Jogging & 35 & 12 of 21 \\
Playing & 21 & 10 of 21 \\
Sitting with a pram & 2 & 2 of 21 \\
\hline
\end{tabular}


Table 2 shows that frequent activities were either long-stay passive activities or transitory activities. Both types were typical of a variety of age and user-groups. Transitory activities ranged from simply walking, cycling or roller skating as transportation to variations such as walking a child, pushing a pram, and walking a dog that may be undertaken for more recreational reasons, and to pure recreation such as jogging. Parents were often seen sitting with prams, or dog walkers with dogs, while people walking with children were often engaged in more active participation, either having a little game along the way, or in any favoured area on the lawn. Those involved in long-stay passive occupations were most often sitting on benches or on the grass, in groups, in pairs or individually. Usage in Tivoli was age and gender-balanced.

Jakopic's Promenade, the central structural feature of the park, which is linked to the main park entrance at the eastern end of the park, is a setting for walking, meeting and sitting on benches for all generations, either in groups of friends or families, or in pairs or individually. For families, the promenade is also a place for short occasional play along the walk or rest on a bench. Sitting on benches is popular all over the park, as is sitting freely on the grass. The latter is popular above all with young people, teenagers, young adults and families. Settings conducive to such activities are green areas with scattered trees or groups of trees. Settings without trees are usually popular for active pursuits such as frisbee and ball games and children's play.
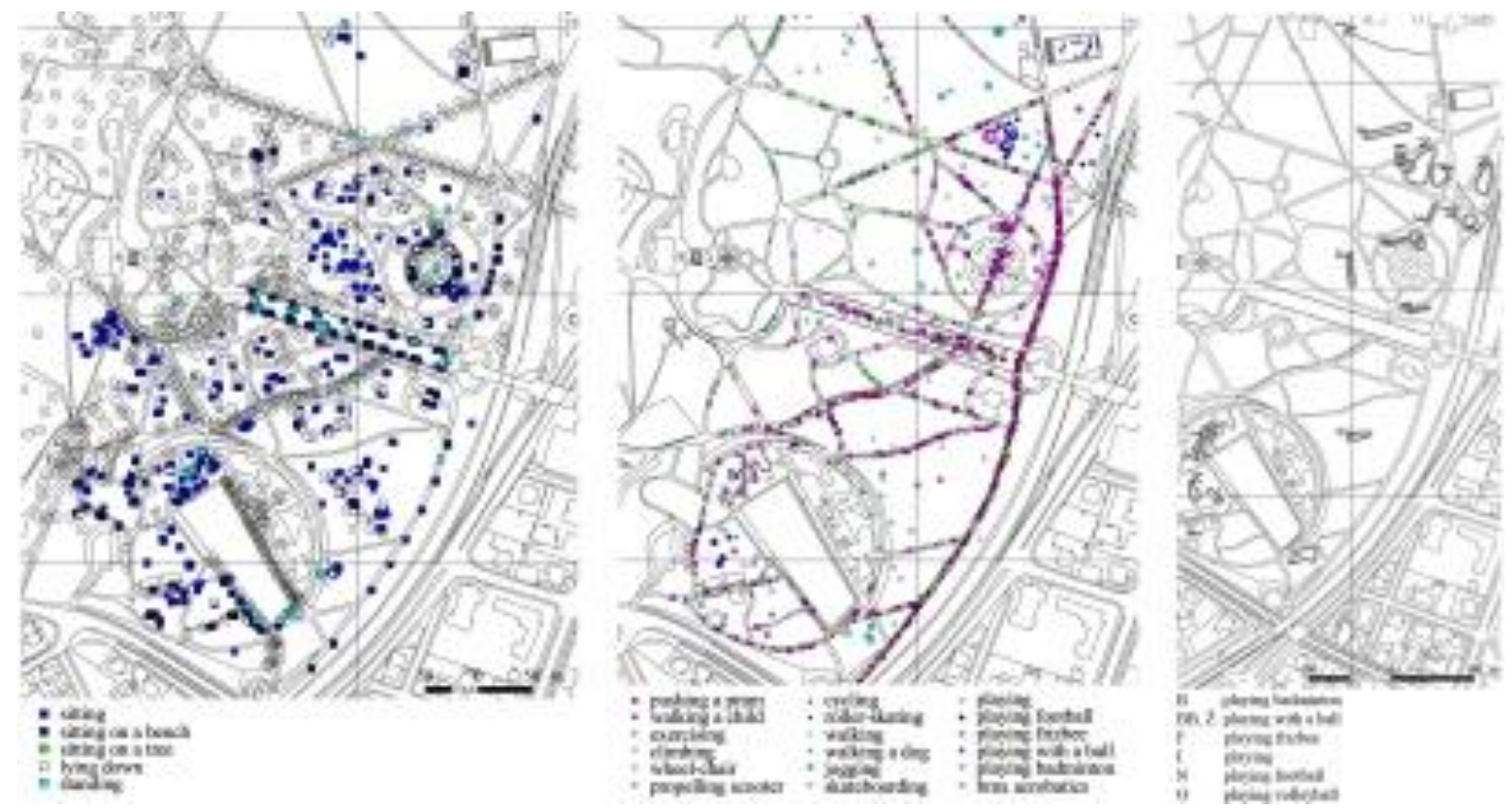

Figure 3: A composite maps showing cumulative behaviour patterns over the entire observation period, specifying a: long-stay passive activities, b. transitory and long-stay active activities, and c. occupancies with long-stay active activities in Tivoli (source: Goličnik, 2005, Goličnik 2006).

\section{Zvezda}

Zvezda Park is located at the intersection of important routes in the city centre. Its physical structure also emphasises the sense of directions and therefore encourages transitory usages. Pedestrians, cyclists and roller-skaters were observed. Characteristic transiting users were also parents pushing prams, families walking children, or an adult walking a child. As Zvezda park is a place for transitory activities, it is therefore also a place for chance and arranged meetings. The latter are characteristic for bigger groups. Especially high levels of 
transitory activities and a sizable number of people standing at the edges of the park (waiting for buses) lend the place the character of a square, whereas sitting or lying on the grass are activities typical of a park. Since the square has been closed down to peripheral traffic, car parking and bus stops eliminated, and the pavement texture of paths crossing the area changed, Zvezda is becoming more and more park-like.

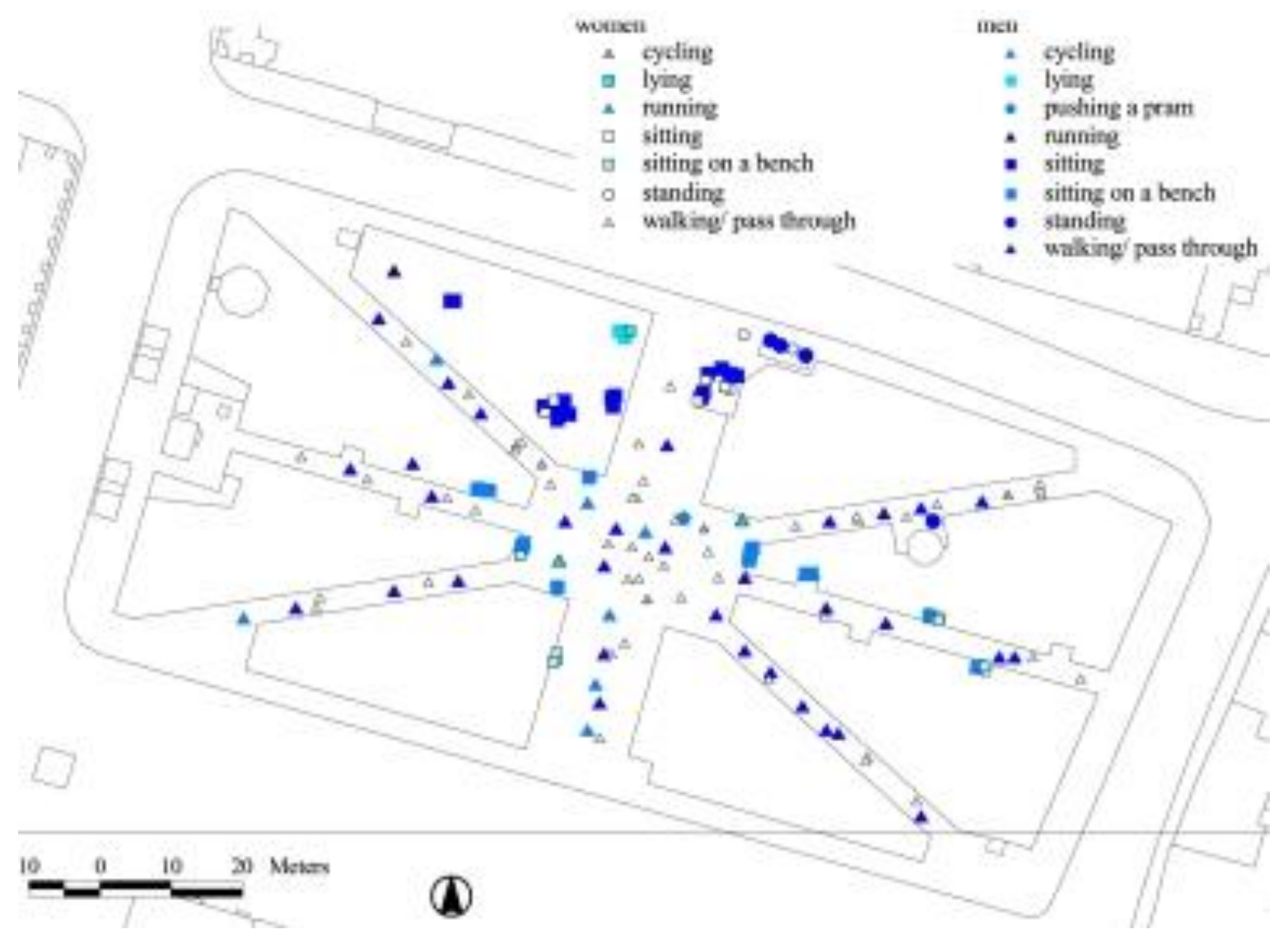

Figure 4: Typical daily pattern of usage in Zvezda, recorded in good weather conditions, afternoon during the week (source: Goličnik, 2005).

Table 3: Intensity and frequency of activities in Zvezda over the entire observation period.

\begin{tabular}{lll}
\hline Activity & Max number & Frequency \\
\hline Walking & 139 & 15 of 15 \\
Cycling & 26 & 14 of 15 \\
Sitting on a bench & 36 & 13 of 15 \\
Standing & 66 & 12 of 15 \\
Sitting & 33 & 10 of 15 \\
Pushing a pram & 5 & 8 of 15 \\
Walking a child & 6 & 7 of 15 \\
Roller skating & 9 & 6 of 15 \\
Sitting around a table & 25 & 4 of 15 \\
Lying & 4 & 3 of 15 \\
Walking a dog & 2 & 3 of 15 \\
Playing & 2 & 3 of 15 \\
Standing with a pram & 1 & 1 of 15 \\
Sitting with a dog & 1 & 1 of 15 \\
\hline
\end{tabular}


In terms of frequency and numbers, sitting freely on the grass and sitting on benches are equal. Sitting freely on the grass is mostly characteristic for young people, often in bigger groups. Smaller groups of up to five were usually single-gender. Sitting on benches was recorded for all age groups and both genders. Play, a characteristic activity for Tivoli, was practically not recorded in Zvezda; there were few exceptions when small children played for a short period informally while waiting with their parents for a bus.

\section{Argentinski Park}

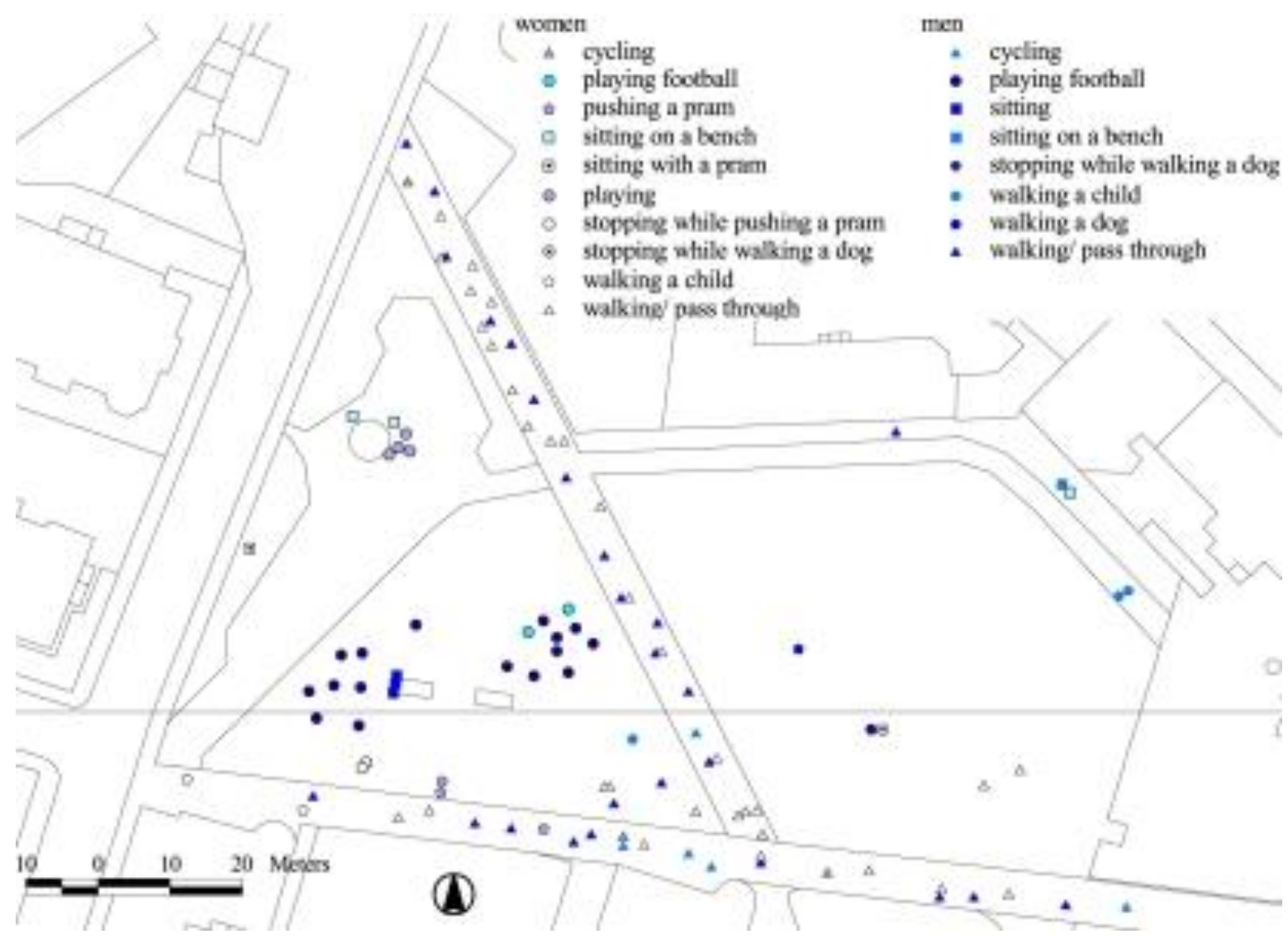

Figure 5: Typical daily pattern of usage in Argentinski Park, recorded in moderate weather conditions, afternoon during the week (source: Goličnik, 2005).

Table 4: Intensity and frequency in engagement with activities in Argentinski park within the entire observation period.

\begin{tabular}{lll}
\hline Activity & Max number & Frequency \\
\hline Walking & 81 & 10 of 10 \\
Cycling & 10 & 10 of 10 \\
Sitting on a bench & 8 & 8 of 10 \\
Walking a dog & 3 & 7 of 10 \\
Sitting & 6 & 6 of 10 \\
Pushing a pram & 5 & 5 of 10 \\
Playing & 5 & 5 of 10 \\
Playing at the playground & 10 & 5 of 10 \\
Sitting on a bench with a pram & 1 & 4 of 10 \\
Playing football & 18 & 3 of 10 \\
Walking a child & 5 & 3 of 10
\end{tabular}




\begin{tabular}{lll} 
Standing & 4 & 3 of 10 \\
Roller skating & 3 & 2 of 10 \\
Playing with a ball & 3 & 1 of 10 \\
Walking a child \& pushing a pram & 1 & 1 of 10 \\
\hline
\end{tabular}

Argentinski Park is similar to Tivoli as regards activities, but the intensity and frequency of use were weaker. Any long-stay activity, either passive such as sitting on a bench or active such as playing ball games or using open access playground equipment, reflects the proximity of school, kindergarten, and residential areas. There were pick-occupancies recorded straight after school/kindergarten (i.e. in the observation period $4-7 \mathrm{pm}$ ). Occasionally, groups of kindergarten children also visited the park in the morning period (i.e. 10 am-noon). Transitory activities, mostly walking, are significant as the park offers a short cut to administrative and service zones of the city centre.

\section{Discussion}

When discussing social behaviour as an informative phenomenon for spatial planning and environmental design, it is important to learn first of all what people do in order to gain the empirical knowledge required to guide planning and design practice. Other essential information is where and when people engage in physical activities in places, the duration of these activities, and how much space they require. This chapter discusses the principles gained from observation and behaviour mapping as a source of empirical knowledge which can support and inform planning, design and decision making for socially sustainable spatial practices. A number of principles are looked into in more detail as to their relevance and applicability for place design, green structure planning, and decision making. The discussion is based on GIS behavioural maps reproduced upon manually gathered data on the maps of the observed settings, which allow metric distance analysis between the depicted users and spatial structures as well as among users themselves. To strength the universal measures and the reliable applicability of empirical knowledge, comments are based not only on Ljubljana case studies but also on empirical evidence collected on central parks in Edinburgh, UK, in May, 2002 (Goličnik, 2005).

\section{Spatial qualities of settings and their correlation with usage}

The empirical knowledge about usage-spatial relationships in park settings gained from observation and behaviour mapping in Edinburgh, UK, in May 2002 and Ljubljana, Slovenia, in May 2003, shows that groups of trees, some prominent single trees, well-defined edge or any other objects can play a crucial role in spatial occupancies such as sitting. Hence, articulation and the placement of uses in a place relying on a certain distance from such objects really matters. For passive usage, e.g. sitting, it is reflected in occupancies at a distance of at least 5 metres from transparent edges (e.g. tree lines along pathways of the patches, predominantly without trees); congregations right up against a solid edge, whether a steep slope or a bank; and in the areas of smaller groups of trees or solitaires. In large grass areas with transparent edges, the buffer between path/avenue and people sitting may be as wide as 15 meters. For more details see Goličnik and Ward Thompson (2010). 

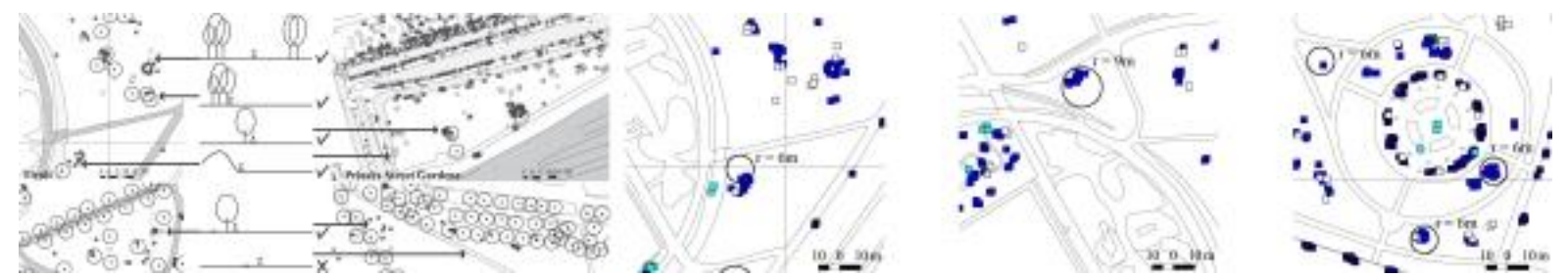

Figure 6: Empirical evidence for conducive settings for long-stay passive usages such as sitting, also showing a minimum space allowing sitting beyond appropriate edge zone (source: Goličnik, 2005).

The results also show that, even if the lawn patch is large, if it is not articulated unless any temporary articulation is available - uses such as sitting or lying down are less likely to occur. However, not only physical-spatial definitions may direct uses in a certain spatial occupancy: the presence of other uses can to a certain degree perform this function as well. Mainly larger groups of active participants can articulate places and, in so doing, create spaces for themselves and for others (Figure 2).
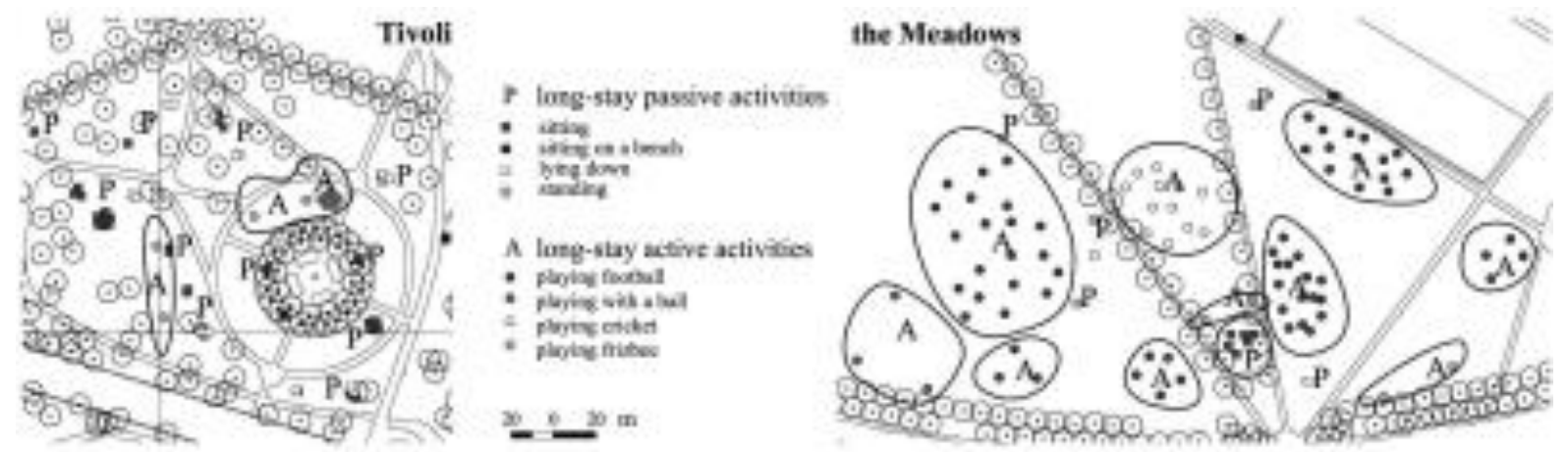

Figure 7: Boundaries in a place due to uses occupancies of territories (source: Goličnik, 2005).

Activities, especially those significant for active group games, form patterns buffered by voids: the buffer between an edge and active users (see A in Figure 8 above); and buffers between a number of adjacent active groups occupying different territories (see $\mathrm{B}$ and $\mathrm{C}$ in Figure 8 above). Conjectures about their importance may provide crucial clues about supplementary spaces required for comfortable overall co-habitation. For example, a point contact on the shorter or narrower sides of areas of occupancy (B in Figure 8 above) and inbetween space along such areas ( $\mathrm{C}$ in Figure 8 above) is relevant especially where occupancy is high. Point contact is the minimum distance between two long-stay active activities at the closest points between them. In practice it is almost always about 4 meters. Activity buffer spaces between three or more active occupancies differ in shape, depending on the shape of the green patch ( $\mathrm{C}$ in Figure 8 above). However, further analysis shows that an abstract form that can describe the minimum activity buffer space commonly needed between groups of activities is a circle of $20 \mathrm{~m}$ radius (Figure 8 below). 


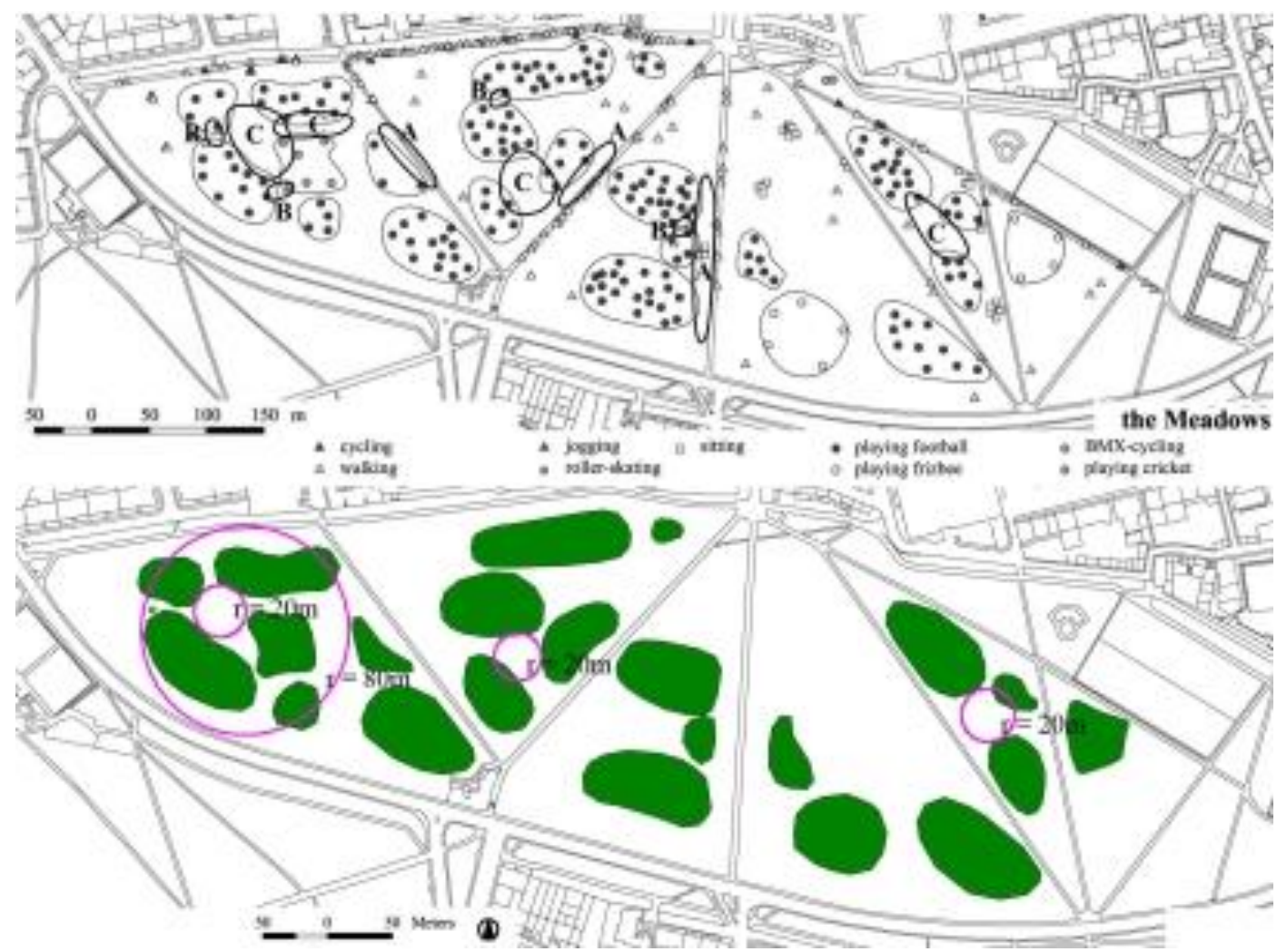

Figure 8: Types of voids (above) (sorce: Goličnik, 2005) and relationships between patch's size and shape and its occupancy (below) (source: Goličnik and Ward Thompson, 2010).

Further discussion is needed on active life styles, public health, and practical planning measures encouragaging healthier lifestyles among urban residents on the basis of detailed examination of long-stay active park occupancy behaviour patterns (Goličnik, 2005). Our results show that the distances activities take to the inner and outer edges of parks differs. For the Meadows, the biggest and most non-articulated place in the entire study, the distance between any part of an inner edge and an activity along it can vary from $35 \mathrm{~m}$ to $2 \mathrm{~m}$ (average $9 \mathrm{~m}$ ); the shortest distances between an activity and an inner edge in every daily pattern studied was usually between $2 \mathrm{~m}$ and $4 \mathrm{~m}$. The analysis also showed that a $4 \mathrm{~m}$ buffer zone between an activity and an inner edge of the park was usually taken by compact bigger groups, and less than that by less compact but not necessarily smaller groups, e.g. frisbee games as opposed to football or other ball games. The distance between any outer edge of the park and an activity along it does not vary as greatly. It ranges from $8 \mathrm{~m}$ to $20 \mathrm{~m}$ in the case of a solid outer edge of the Meadows (along the northern border), most often about 13m; and from $15 \mathrm{~m}$ to about $30 \mathrm{~m}$ from the open edge (southern border) for any long-stay active activity. A distance of over $30 \mathrm{~m}$ is the most frequent maximum, whereas the most frequent minimum distances ranged from $20 \mathrm{~m}$ to $25 \mathrm{~m}$. 

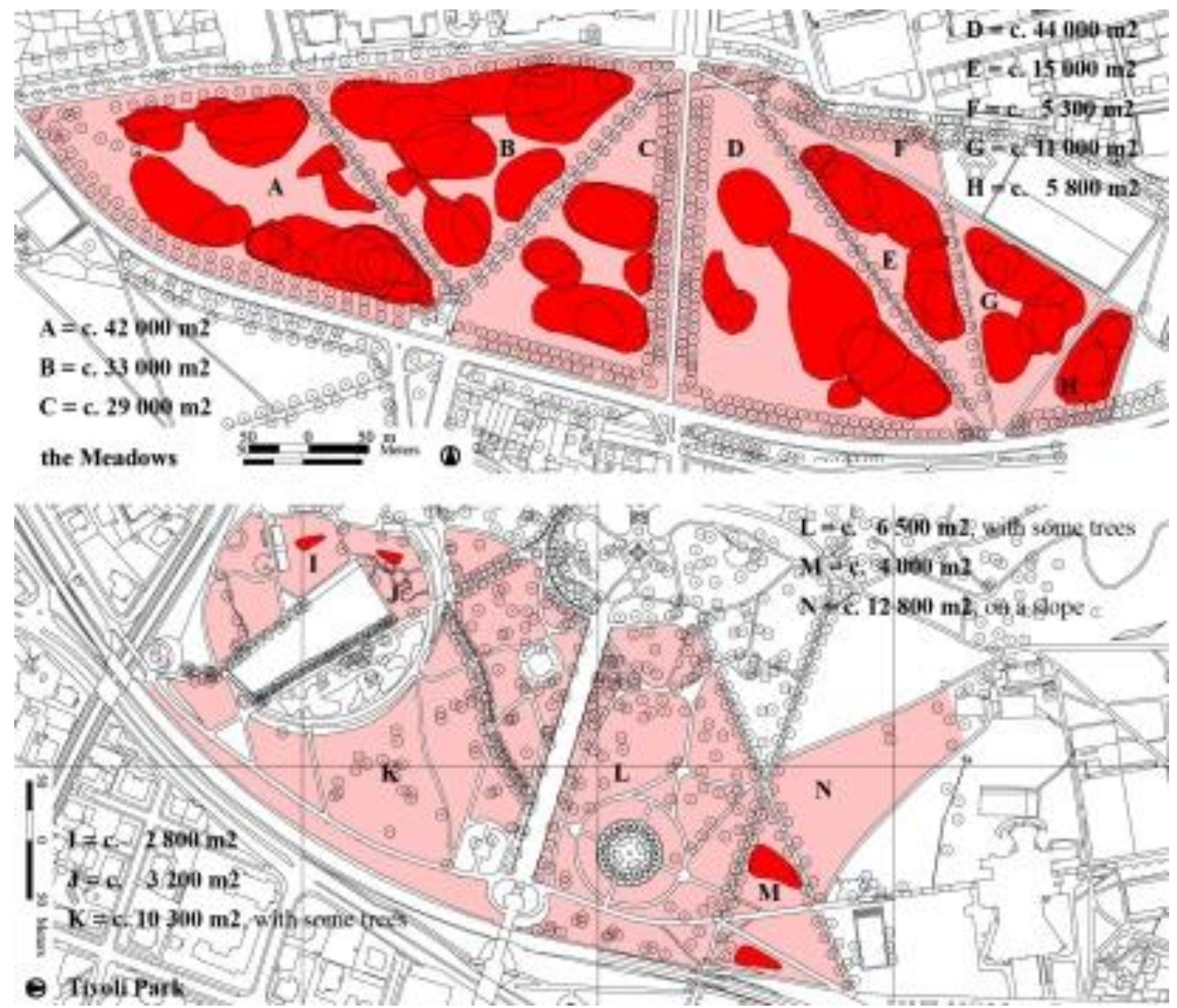

Figure 9: Suitability of park settings for long stay active occupancies (source: Goličnik, 2005).

The aspects influencing the usage-spatial relationship in positioning active long-stay uses in a park setting are the size and shape of activity spaces and compactness of the groups using them. Thus such initial metric distances can be additionally informed with surfaces and the number of people per surface occupying the territory. Goličnik and Ward Thompson (2010) shows that large groups demand clear areas of at least $3000 \mathrm{~m}^{2}$ (e.g. informal football games; groups of $15-20$ people need $3000 \mathrm{~m}^{2}-5000 \mathrm{~m}^{2}$ and a longitudinal space; informal games other than football require $1000 \mathrm{~m}^{2}-3000 \mathrm{~m}^{2}$ spaces; and both need some buffer areas around them). The empirical observation data on the Meadows suggests that one of the reasons for low participation in football in Tivoli, especially by adults, might be that there is simply not enough space. The big patches in Tivoli range from about $6500 \mathrm{~m}^{2}$ to $10000 \mathrm{~m}^{2}$. Although they might appear suitably large for such occupancy, the trees scattered across them reduce their potential for such a use. The biggest patch with no trees (a triangle ca. $4000 \mathrm{~m}^{2}$ ), along the main walkways through the park was used once by a large group of children playing football ( $\mathrm{M}$ in Figure 16). The biggest patch with no trees in northern Tivoli ( $\mathrm{N}$ in Figure 16) is on a slight slope and therefore unsuitable for football.

\section{Cumulative spatial capacities of places}

As opposed to the knowledge gained from daily patterns, overall views of occupancy patterns can show the under- or overuse as well as the cumulative capacities of places and thus indicates spatial capacities for users. For example, the intensity of occupancies shows 
where activities with similar participation intensities took place in the park (Figure 10 above). This is linked with types of activities and popularity of settings for their presence in a place. Spatial settings such as well-defined corners seem popular for all sorts of activities with many participants (e.g. sitting and playing football), as well as those with few participants, (e.g. playing with a ball, street theatre, and standing). All such activities with varying participation take place mostly in peripheral and semi-peripheral areas.

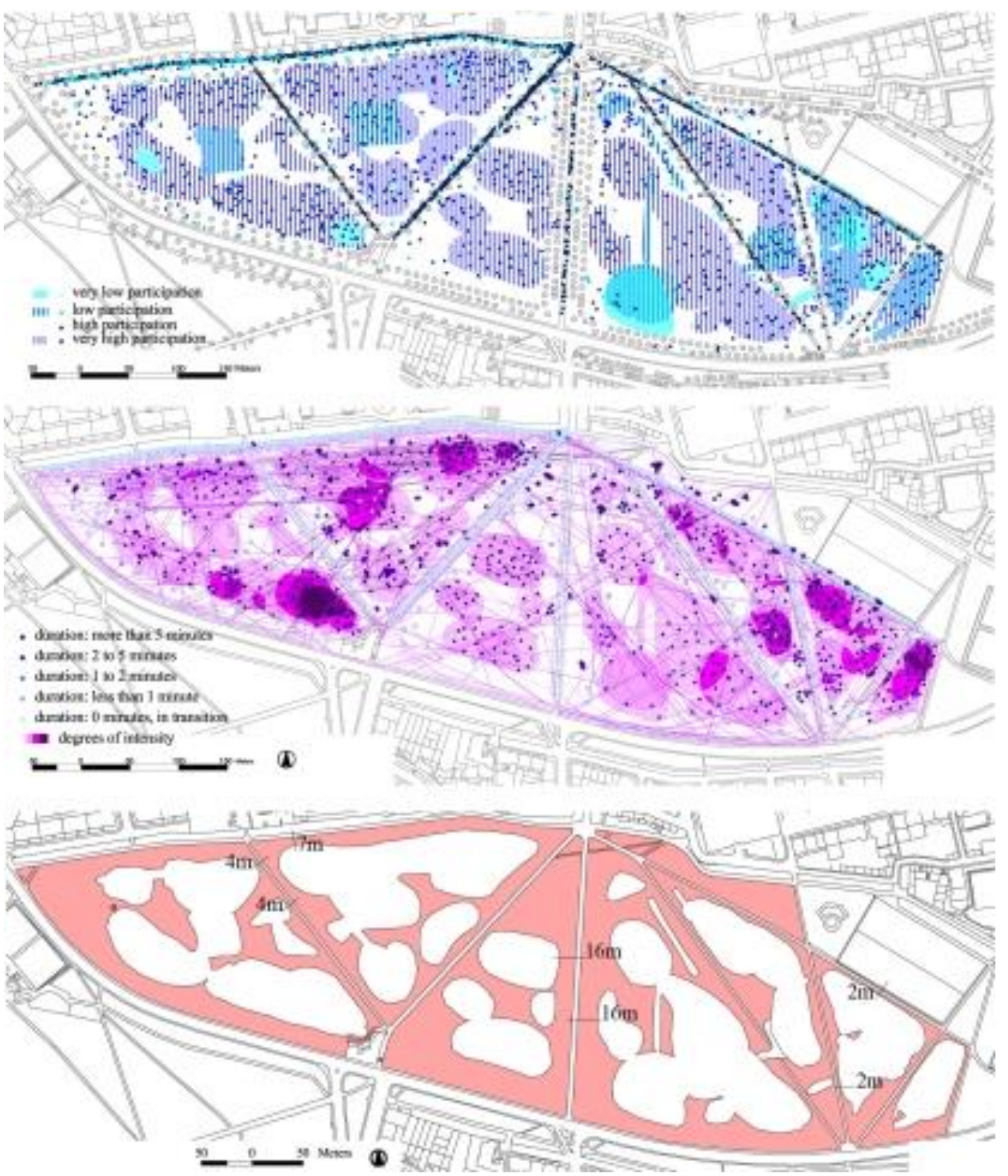

Figure 10: Spatial occupancy arranged with regard to participation of users engaged in any one activity (above), cumulative intensity of temporal-spatial occupancy of the park (middle), and cumulative minimum buffer zone for the park (below) The Meadows, Edinburgh, UK (source: Goličnik, 2005)

Furthermore, the cumulative intensity of temporal-spatial occupancy, from low to high and from transitory to prolonged stays in the park generates knowledge about the levels of shared areas of uses, the frequency of occupancy, and the intensity of usage by one or more different activities significant for a particular setting or territory within a designed place. This is reflected by the popularity of corner occupancy (Figure 10 middle). As opposed to a 
situation of different levels of occupancy (Figure 10 above and centre), Figure 10 below shows the minimum cumulative buffer zone of the park, an area which always remained unused: about $2 \mathrm{~m}$ from the inner edges, about $16 \mathrm{~m}$ from outer open edges and about $7 \mathrm{~m}$ from outer solid edges. The main communication route across the park, lined on each side by a double row of trees, forms a buffer zone similar to that of the open outer edge on the south, i.e. $16 \mathrm{~m}$.

\section{Informing networks of places for socially responsive green structure}

The key elements of green infrastructure in cities and towns, especially city centres, are usually parks. No matter what their size and shape, parks are often considered negative or soft spaces, places of implicit limits (Trancik, 1986). This paper shows that in parks where physical limits are well defined, environments suitable for occupancy are easily recognised and realised; where voids are larger and the physical limits are farther apart, uses themselves structure the resilience of the potential environment to become effective for one or more of them. Thus, a structure is given to loose-fit spaces. In parks, where large voids are usually one of the basic spatial constituents, the question how loose-fit landscapes can be (in)formed by uses is relevant here. Making a point about park design, Ward Thompson (2002) refers to Dovey's critical comments on La Villette, Paris, that "the emphasis on static, visual qualities of space does not in fact make for loose and free use of space, but one where use is highly controlled and limited" (Dovey 2000 in Ward Thompson, 2002: 70). Recognising the potentials and problems of/for loose-fit spaces in designed places, this paper considers one aspect of their examination through occupancies, and seeks insight into how this flexible concept of loose-fit landscapes of larger central parks (in a European context) can be implemented and closely considered.

When dealing with socio-spatial issues, the focus is usually not only on gaining detailed information about the shapes, dimensions and spatio-temporal patterns of usage-spatial relationships and usage-usage relations in particular settings but also on the social aspects of green infrastructure planning and connections between green areas, their accessibility and proximity to various services or residential areas. To obtain the physical dimensions and quantified references required for planning, such research usually uses GIS tools and analysis. From a technical point of view there is a variety of approaches for calculating and evaluating accessibility with regard to actual accesses (e.g. Schipperjin et al., 2013) using centroids (e.g. Kaczynski et al., 2009). However, this method ignores open space shape and size, which may lead to the misinterpretation of proximity. Therefore improvements and advanced approaches tackling such difficulties (e.g. Apparico and Seguin, 2006; Nicholls, 2001; Koohsari et al., 2013) are important to obtain consistency. Knowledge about sizes and shapes of places in function of the size and shape of activities taking place there can supplement information about proximities and accessibilities and contribute to the evaluation of green infrastructure elements in terms of the qualitative dimensions of socio-spatial relations.

In the interests of planning and desigining socially responsive urban green infrastructures, proximity and accessibility studies need to be supplemented by studies addressing the actual articulation of places and their conduciveness to outdoor activity as exemplified by this paper. Such an integral approach would address issues of public health and general well-being for the urban population more comprehensively, and better enable urban and spatial planning to provide specific and focused solutions for particular, localized public health issues.

\section{Lessons learnt for Central, Eastern and South-Eastern European perspective}

This paper has focussed on a very fine scale on the dimensions, shapes, intensities and character of uses in places to gain bottom-up insights for planning practice and design. Even if the generalisations presented as empirical knowledge are still rather speculative, they can 
contribute considerably to our understanding of the social dimensions of green spaces, because the existing theory and guidelines on the built environment are now backed by data on large open space occupancies. At the same time, it is important to bear in mind the limitations of findings that depend either on accurate recording of the facts or consideration of other aspects that may influence space occupancy.

The socio-economic context, the functions and density of the surrounding area may vary and are certainly likely to influence the activities and level of use within a space. In this study (Goličnik, 2005), the sites chosen were roughly comparable with regard to such considerations but this potential limitation must be recognised before generalising to other parks in other (e.g., suburban) parts of other towns and cities. Well-used (and wellmaintained) city parks are likely to be perceived as safe places to visit, sit on the grass, etc., but this may not be true for emptier or poorly maintained spaces, or where there is no surrounding land use that provides informal policing of the area.

However, the cases under discussion proved to be comparable. Both cities, Edinburgh (UK) and Ljubljana (Slovenia) are middle-sized European capital cities with a relatively small total population (Edinburgh about 450,000, Ljubljana about 300,000). Both are important national and international cultural, educational, and political centres; they have a similar atmosphere in terms of daily routine. Both are located in the mid-latitude temperate climate zone, Edinburgh in the oceanic zone, Ljubljana in the continental zone. This causes some differences at certain times of the year, but in mid-spring, a popular season for outdoor activities, they are quite similar, especially when conditions are dry, no matter if it is sunny or windy. A comparable number and typology of selected places representing popular, central public open spaces of different sizes and micro-spatial contexts were selected for study within an area of about $2 \mathrm{~km}^{2}$ in each city. In central, eastern and south-eastern Europa cities of such dimensions are very common. The findings of our bottom-up approach can therefore contribute directly to green infrastructure planning and urban design.

\section{Conclusion}

The aim of this paper has been to provide socially informed concepts and measures for the green infrastructure and to show the potential of behaviour patterns and their characteristics for urban planning and design, not only to provide thresholds and evidence-based guidance, but also to link public health research and urban planning and design in the interests of enhancing the quality of life in cities and towns. If one of the goals of public health is to increase the amount of physical activity people choose to engage in, appropriate environments must be provided. To this end, it is crucial to understand what usage-spatial and usage-usage conditions must pertain if particular activities are to develop to the full.

\section{References}

Apparico, P. \& Seguin, A.M. (2006) Measuring the accessibility of services and facilities for residents of public housing in Montreal. Urban Studies, 43, pp. 187-211. DOI: $10.1080=00420980500409334$

Baker, R.G. (1976) On the nature of the environment. In: Prohansky, H.M., Ittelson, W.E. \& Rivlin L.G. (eds.) Environmental psychology: People and their physical settings ( $2^{\text {nd }}$. ed.), pp. 12-26. New York, Holt, Rinehart \& Winston.

Bourasa, S.C. (1991) The aesthetics of landscape. London, Belhaven.

Coombes, E., van Sluijs, E. \& Jones, A. (2013) Is environmental setting associated with the intensity and duration of children's physical activity? Findings from the SPEED GPS study. Health and Place, 20, pp. 62-65. DOI: 10.1016/j.healthplace.2012.11.008 
Dunton, G.F., Almanza, E., Jerrett, M., Wolch, J. \& Pentz, M.A. (2014) Neighbourhood park used by children: Use of accelerometry and global positioning systems. American Journal of Preventive Medicine, 46, pp. 136-142. DOI: 10.1016/j.amepre.2013.10.009.

ESRI, ArcView 3.3

Evenson, K.R., Wen, F., Hillier, A. \& Cohen, D.A. (2013) Assessing the contribution of parks to physical activity in diverse communities of two U.S. cities: an observational study. American Journal of Preventive Medicine, 34, pp. 299-305. DOI: 10.1249/MSS.0b013e318293330e

Gibson, J.J. (1979) The ecological approach to visual perception. Boston, Houghton Mifflin.

Goličnik, B. \& Ward Thompson, C. (2010) Emerging relationships between design and use of urban park spaces. Landscape and Urban Planning, 94, pp. 38-53. DOI: 10.1016/j.landurbplan.2009.07.016

Goličnik, B., Mujkić, S., Nikšič, M. \& Tominc, B. (2007) Vedenjski zemljevidi za vitalno mesto: Inovativna uporaba GIS-ov za spremljanje in prikaz prostorskih in neprosrtorskih dejavnikov oživljanja mestnega središča. Ljubljana, UIRS.

Goličnik Marušić, B. \& Marušić, D. 2012. Behavioural maps and GIS in place evaluation and design. In: Alam, B. M. (eds.) Application of geographic information systems, pp. 113139. Rijeka, Intech.

Goličnik Marušić, B. (2011) Analysis of patterns of spatial occupancy in urban open space using behaviour maps and GIS. URBAN DESIGN international, 16, pp. 36-50. DOI: 10.1057/udi.2010.20

Goličnik Marušić, B. (2009) Analiza in preveritev učinkovitosti vedenjskih zemljevidov in GIS-a kot orodja urbanističnega oblikovanja za izboljšanje načrtovanja: zaključno poročilo o rezultatih raziskovalnega projekta;. Ljubljana, UIRS

Goličnik, B. (2006) Vedenjski zemljevidi ljubljanskih trgov in parkov: Novi iizzivi in pogledai na načrtovanje in urejanje prostora. Urbani izzv publikacije. Ljubljana, UIRS

Goličnik, B. (2005) People in place: A configuration of physical form and the dynamic pattrens of spatial occupancy in urban open public space. $\mathrm{PhD}$ thesis. Edinburgh, ECA, Heriot-Watt University.

Hardman, A.E. \& Stensel, D.J. (2003) Physical activity and health: The evidence explained. Washington DC, Trust for public land.

Hartig, T., Evans, G.W., Jamner, L.D., Davis, D.S. \& Garling, T. (2003) Tracking restoration in natural and urban field settings. Journal of Environmental Psychology, 23, pp. 109123. DOI: 10.1016/S0272-4944(02)00109-3

Hartig, T. (2007) Three steps to understanding restorative environments as health resources. In: Ward Thomposn C. \& P. Travlou (eds.) Open space - People space, pp. 163-179. Abingdon UK, Taylor and Francis.

Heft, H. (2010) Affordance and the perception of landscape. In: Ward Thomposn, C., Aspinall, P. \& Bell, S. (eds.) Innovative approaches to research landscape and health: Open space: People space 2, pp. 9-32. Abingdon UK, Routledge.

Kaczynski, A.T., Potwarka, L.R., Smale, B.J.A. \& Havitz, M.E. (2009) Association of parkland proximity with neighbourhood and park-based physical activity: variations by gender and age. Leisure Sciences: An Interdisciplinary Journal, 31, pp. 174-181. DOI: 10.1080/01490400802686045

Kaplan, R. \& Kaplan, S. (1989) The experience of nature: A psychological perspective. Cambridge, Cambridge University.

Koohsari, M.J., Mavoa, S., Villanueva, K., Sugiyama, T., Badland, H., Kaczynski, A. T. \& Owen, N. (2015) Public open space, physical activity, urban design and public health: Concepts, methods and research agenda. Health and Place, 33, pp. 75-82. DOI: 10.1016/j.healthplace.2015.02.009 
Koohsari, M.J., Badland, H., Giles-Corti, B. (2013) (Re)Designing the built environment to support physical activity: Bringing public health back into urban design and planning. Cities, 35, pp. 294-298. DOI: 10.1016/j.cities.2013.07.001

Le Corbusier (1951) The Modulor. London, Faber and Faber

Le Corbusier (1971) The city of tomorrow and its planning. London Architectural Press, $8^{\text {th }}$ edn.

Nicholls, S. (2001) Measuring the accessibility and equity of public parks: A case study using GIS. Managing Leisure, 6, pp. 201-219. DOI: 10.1080/13606710110084651

Quigg, R., Gray, A., Reeder, A.I., Holt, A. \& Waters, D.L. (2010) Using accelerometers and GPS units to identify the proportion of daily physical activity located in parks with playgrounds in New Zealand children. Preventive Medicine, 50, pp. 235-240. DOI: 10.1016/j.ypmed.2010.02.002

Sallis, F., Owen, N. \& Fisher, E.B. (2008). Ecological models of health behaviour. In: Glanz, K., Rimer, B.K. \& Vismanath, K. (eds.), Health behaviour and health education: Theory, research, and practice, pp. 565-485. San Francisco, Jossey-Bass.

Sallis, J.F., Floyd, M.F. Rodriguez, D.A. \& Saelens, B.E. (2012) Role of built environmnets in physical activity, obesity and cardiovascular disease. Circulation, 125, pp. 729-737. DOI: 10.1161/CIRCULATIONAHA.110.969022

Schipperjin, J., Bentsen, P. Troelsen, J., Toftager, M., Stigsdotter, U.K. (2013) Associations between physical activity and characteristics of urban green space. Urban Forestry and Urban Greening, 12, pp. 109-116. DOI: 10.1016/j.ufug.2012.12.002

Sugiyama, T. \& Ward Thompson, C. (2008). Associations between characteristics of neighbourhood open space and older people's walking. Urban Forestry and Urban Greening, 7, pp. 41-51. DOI: 10.1016/j.ufug.2007.12.002

Trancik, R. (1986) Finding lost space: Theories of urban design. New York: Van Nostrand Reinhold.

Ward Thompson, C. (2013) Activity, exercise and the planning and design of outdoor spaces. Journal of Environmental Psychology, 34, pp. 79-96. DOI: 10.1016/j.jenvp.2013.01.003

Ward Thompson, C. (2002) Urban open space in the $21^{\text {st }}$ century. Landscape and urban planning, 60, pp. 59-72. DOI: 10.1016/S0169-2046(02)00059-2 